\title{
A TROUBLESOME LESION OF THE LARYNX: LOBULAR CAPILLARY HEMANGIOMA
}

\author{
Oguz Egilmez ${ }^{1}$, Lokman Uzun ${ }^{1}$, Sidika Ozkanli ${ }^{2}$, Mahmut Kalcioglu ${ }^{1}$, Muhammet Tekin ${ }^{1}$ \\ ${ }^{1}$ Istanbul Medeniyet University, School of Medicine, \\ Department of Otorhinolaryngology, Istanbul, Turkey \\ ${ }^{2}$ Istanbul Medeniyet University, Goztepe Training and Research Hospital, \\ Department of Pathology, Istanbul, Turkey
}

\begin{abstract}
Lobular capillary hemangioma ( $\mathrm{LCH}$ ), which is also known as pyojenic granuloma, is a benign and vascular lesion of the skin and mucous membranes and mostly seen in females between 20-40 years of age. Although the etiology of the condition is still unknown, some conditions, such as trauma, poor oral hygiene, viral or fungal infections, and periodontal and gingival diseases are considered to be related to the formation of LCH. It mostly seems in cheek and oral cavity in head and neck region. Larynx localization of LCH is very rare. We present a case of LCH in a 47-year-old male and review the literature.
\end{abstract}

Keywords: lobular capillary hemangioma, pyogenic granuloma, larynx, trauma, dysphonia, vocal fold

\section{INTRODUCTION}

Lobular capillary hemangioma (LCH) is a benign lesion of the skin and mucous membranes. It has a diagnostic, lobular arrangement of capillaries, which is distinguished histologically from granulation tissue (1). This type of lesion is mostly seen in female patients between 20-40 years of age (2). The condition was first described in 1897 by Poncet and Dor (3). While the exact etiology is still unknown, trauma, poor oral hygiene, and gingival and periodontal diseases and infections are considered to be contributing factors (4). The head and neck region is

\author{
Address for correspondence: \\ M. Tayyar Kalcioglu, M.D., Professor \\ Istanbul Medeniyet University, School of Medicine, \\ Goztepe Training and Research Hospital Dr. Erkin Cad. \\ 34722 Kadikoy \\ Istanbul, Turkey \\ Mobile: +90 5334330695 \\ e-mail: mtkalcioglu@hotmail.com
}

Received: November 3, 2015

Accepted: December 1, 2015 the main location of LCH. It especially seems in gingiva and clinically presented with a soft pedunculated lobular mass that grows rapidly and occasionally bleeds (5). Larynx localization is, extremely rare. A 47-year-old male patient with LCH of the left vocal fold was presented in this case report. In this paper, differential diagnosis and treatment options of $\mathrm{LCH}$ are discussed with literature review.

\section{CASE REPORT}

A 47-year-old male patient was referred to the university hospital with complaints of hoarseness and dysphonia. During the last two months, he had experienced voice fatigue and the sensation of a foreign body being lodged in his throat; he also complained about discomfort while swallowing liquids or solids. Previous surgery or trauma history, previous history of illness and drug use was asked and learned that he had only inguinal hernia operation six years before under general anesthesia with endotracheal intubation.

Physical and endoscopic examinations were performed. The oral cavity and dental conditions 
Oguz Egilmez, Lokman Uzun, Sidika Ozkanli et al.

were normal. Videolaryngoscopic examination revealed varicosities mass located on the vocal process of posterior part of the left vocal fold.

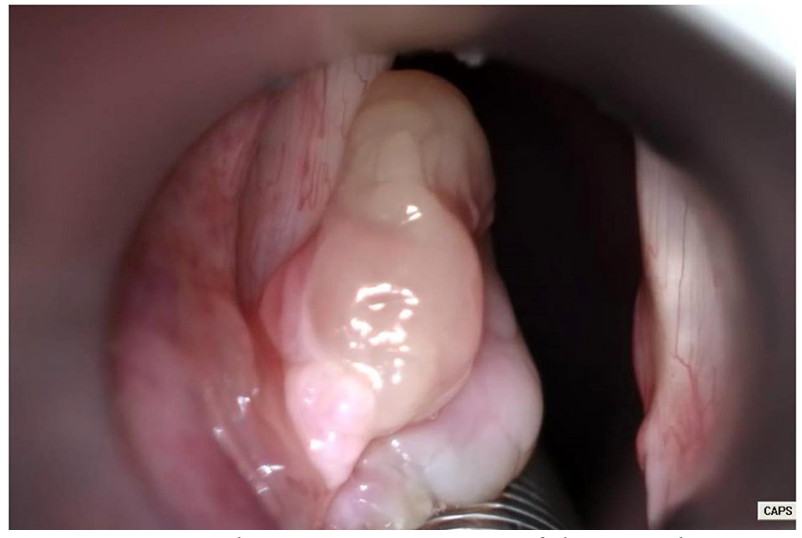

Figure 1. Direct laryngoscopic image of the mass lesion on the posterior part of the left vocal fold

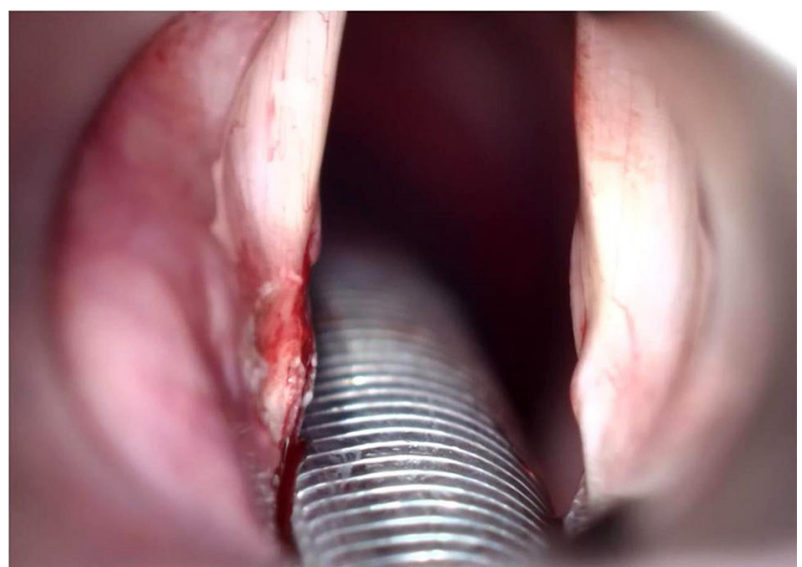

Figure 2. The image of the glottis after surgical excision of the mass

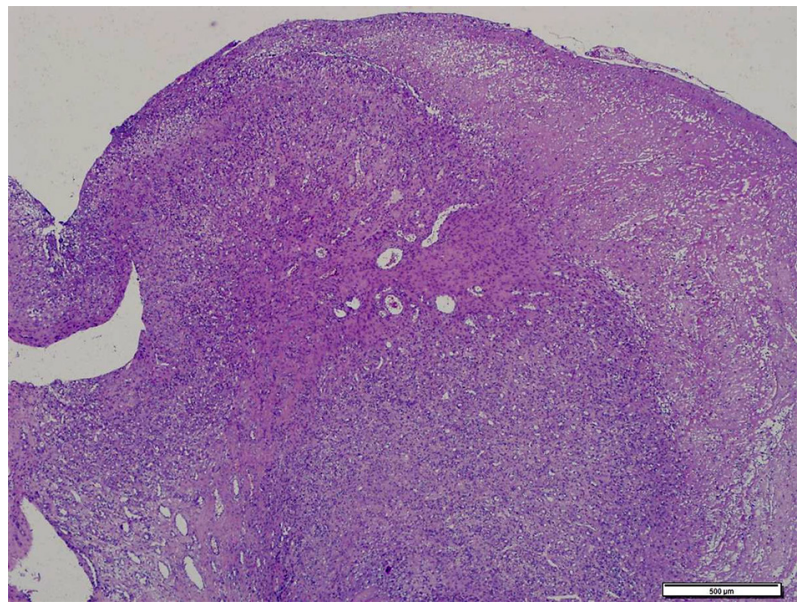

Figure 3. Histopathologic image of the lesion under light microscopy (Staning with HeE; 40x)
Direct laryngoscopy was performed under general anesthesia and a multilobulated, $1 \times 0.8 \mathrm{~cm}$ sized mass, originating from the posterior portion of the left vocal fold obstructing the Rima glottis, was seen (Figure 1). The mass was totally excised surgically (Figure 2). Histopathologic examination revealed ulceration on the surface of the lesion and ulcer floor containing fibrinoid necrosis. Under the ulceration, vascular proliferation had been formed by a large number of capillary vessels, which were separated by fibrotic septae. Mixed-type inflammatory cell infiltration was also seen under the light microscopy (Figure 3). The lesion was therefore diagnosed as $\mathrm{LCH}$. The postoperative course was uneventful. The patient was medicated with antibiotics and anti-reflux therapy. Although it was very small compared to the initial mass, the mass was recurred three months after the surgery (Figure 4). The patient is being followed with these findings.

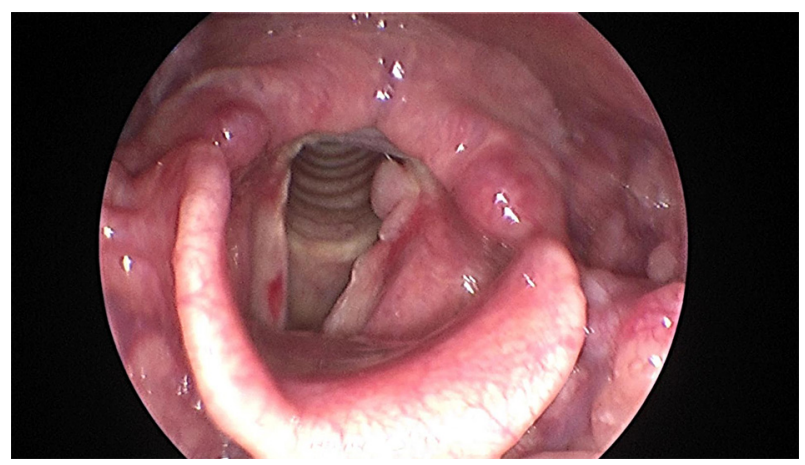

Figure 4. Videolaryngoscopic examination of the patient, postoperative third month

\section{DISCUSSION}

$\mathrm{LCH}$ is characterized by a lobular arrangement of capillaries (1). Some researchers think that this is a hyperproliferative vascular response to infective organisms of low virulence (6). When it was first described by Poncet and Dor, the authors suggested that these organisms were fungi (3). Later, in the nineteenth century, Hertzel reported it as a bacterial infection (7). Recent studies about the etiology of LCH suggest trauma as the main etiologic factor (8) and believe that after a trauma to the mucous membrane, extensive granulation tissue is formed and healing is abnormal, thus leading to LCH (3, 9). Traumatic factors, such as coughing, persistent throat cleaning, prolonged endotracheal intubation, 
previous laryngeal surgeries, and gastric reflux may play a role in the formation of this type of lesion. In our case report, the patient had a history of endotracheal intubation six years ago and that might have caused this lesion. presented a case with a $\mathrm{LCH}$ arising from the vallecula (14). Garrett et al. reported a LCH located the superior aspect of the right arytenoid vocal process (9). In our patient, $\mathrm{LCH}$ was arising from the posterior portion of the left vocal fold (Table 1).

Table 1. The main clinical features of the reported cases with lobular capillary hemangioma in the larynx

\begin{tabular}{|c|c|c|c|c|}
\hline Author & Localization & Etiology & Symptoms & Treatment \\
\hline Karlıdağ et al. ${ }^{6}$ & Epiglottis & $\begin{array}{l}\text { None of the common } \\
\text { etiologic factors }\end{array}$ & $\begin{array}{l}\text { Hemoptysis, } \\
\text { dysphonia }\end{array}$ & Surgery \\
\hline Garrett et al. ${ }^{9}$ & Arytenoid & $\begin{array}{l}\text { Blunt laryngeal } \\
\text { trauma }\end{array}$ & $\begin{array}{l}\text { Voice changes, } \\
\text { shortness of breath }\end{array}$ & $\begin{array}{l}\text { Surgery plus medical } \\
\text { therapy }\end{array}$ \\
\hline $\begin{array}{l}\text { Rechtman and Ar- } \\
\text { mstrong }\end{array}$ & Vocal fold & N.A. & Minimal symptoms & Surgery \\
\hline Lai et al. ${ }^{12}$ & False vocal fold & $\begin{array}{l}\text { Vocal abuse, coug- } \\
\text { hing spells, previous } \\
\text { surgery }\end{array}$ & Dysphonia & $\begin{array}{l}\text { Surgery plus medical } \\
\text { therapy }\end{array}$ \\
\hline Sataloff et al. ${ }^{13}$ & Vocal process & $\begin{array}{l}\text { Vocal abuse, } \\
\text { coughing, throat } \\
\text { cleaning, gastric } \\
\text { reflux }\end{array}$ & $\begin{array}{l}\text { Hoarseness, voice } \\
\text { fatique }\end{array}$ & $\begin{array}{l}\text { Medical, voice } \\
\text { therapy, surgery, } \\
\text { botox injection }\end{array}$ \\
\hline Yakirevitch et al. ${ }^{14}$ & Vallecula & $\begin{array}{l}\text { Endotracheal } \\
\text { intubation }\end{array}$ & Hemoptysis & Surgery \\
\hline Chambres et al. ${ }^{19}$ & Vocal cords & $\begin{array}{l}\text { Nasotracheal } \\
\text { intubation }\end{array}$ & N.A. & N.A. \\
\hline Galos et al. ${ }^{20}$ & Vocal fold & Gastric reflux & Dysphonia & $\begin{array}{l}\text { Medical, voice } \\
\text { therapy, surgery, } \\
\text { botox injection }\end{array}$ \\
\hline Current Case & Vocal process & $\begin{array}{l}\text { Endotracheal } \\
\text { intubation }\end{array}$ & $\begin{array}{l}\text { Hoarseness, } \\
\text { dysphonia }\end{array}$ & $\begin{array}{l}\text { Surgery plus medical } \\
\text { therapy }\end{array}$ \\
\hline
\end{tabular}

The majority of LCH in the body are located in the head and neck region. Partice et al. described the most frequent sites in the head and neck region, which were the cheek $(28.8 \%)$, oral cavity $(13.5 \%$, especially gingiva), scalp (10.8\%), forehead (9.9\%), and eyelid and lips (both 9\%) (7). Case reports in the literature also mention that the nasal septum is another location for LCH (10). Larynx localization is very rare, and only a few cases have been reported (Table 1). Rechtman and Armstrong reported a sixty-yearold male patient with LCH that arose from the posterior portion of the left vocal fold (11). Lai et al. reported a eighty-year-old woman with LCH located on a narrow pedicle arising from the right false vocal fold (12). Sataloff et al. presented a LCH case in which the lesion was based on a stalk attached to the right vocal process and posterior glottis (13). Yahirevitch et al.
Histologically, LCH differ from the granulation tissues because they have a lobular arrangement of capillaries in the deep portion of the lesion $(1,6)$. Mitoses are commonly present and may be numerous. Focal cytological atypia may be seen as a result of degeneration. Superficial infiltration by chronic and acute inflammatory cells is a common finding, but this is seen only in ulcerated lesions. In our case, histopathologically, capillary lobular formation and endothelial and stromal elements with inflammatory infiltrates were revealed under the light microscopy.

Differential diagnosis is important for recognizing the pathology, and determining the appropriate treatment and prognosis of the disease. Some benign and malign lesions, such as hemangioma, hemangioendothelioma, angiofibroma, angiosarcoma, Kaposi sarcoma, Wegener's granuloma and Crohn's 
Oguz Egilmez, Lokman Uzun, Sidika Ozkanli et al.

disease, and granulomatous infectious diseases such as tuberculosis and histoplasmosis, traumatic granuloma, carcinosarcoma, and verrucous and squamous cell carcinoma can be considered in the differential diagnoses of LCH of the larynx $(9,15)$. LCF may sometimes need to be distinguished clinically from other types of capillary hemangiomas. Mucosal lesions with very plump endothelial cells and a high mitotic rate may be readily distinguished by their lobular architecture. It is distinguished from hemangioma histologically and clinically based on its lobular growth pattern, overlying ulceration, fibromyxoid background and acute inflammation (16).

Although some cases occasionally require surgical interventions, the laryngeal LCH can be treated medically. Medical treatment options are anti-reflux therapy, steroids, antibiotics and voice therapy, as well as eliminating factors that cause irritation to the larynx (13). However, observation, cauterization, and surgical excision are the treatment options for laryngeal LCH (17). Surgical therapy can be examined under three subheadings: complete resection with open submucosal resection, laser or microdebrider excision with serial reassessment and intralesional steroid injection with serial assessment (18). The advantages of open submucosal resection are that it is a single-session-procedure, there is no need for long term medical therapy and the pathology can be obtained totally, but the most hazardous disadvantage is that this is an invasive procedure and often requires intensive care unit (ICU) hospitalization after operation. Laser or microdebridder excision is a less invasive procedure than complete resection and there is no need for long term medical therapy, too. But sometimes it may require multiple sessions to resect the disease totally and also there is an increasing risk for subglottic stenosis. Intralesional steroid injection is another type of surgical therapy and it is again less invasive than open submucosal resection and does not require long term medical therapy. This procedure has a disavantage of requiring multiple sessions for total cure and incresing risk for subglottic stenosis as laser and microdebridder excision procedure. In a study reported by Truong et al., patients with airway hemangioma were given systemic propranolol and six out of 7 patients were treated successfully (18). It is not an invasive procedure. This is the most important advantage of this treatment, but this therapy mostly lasted from 6 months to 1 year and there are risks of hypotension, hypoglycemia and bradycardia in some patients. There is not enough knowledge about the risks of long term therapy (18). Sataloff et al. and Galos et al. also reported that for granulomas that refractory to medical or surgical therapy and for recurrent pathologies, it is appropriate to consider botulinum toxin injections into the lateral cricoarytenoid muscles along with local and/or systemic steroid therapy $(13,19) .16 \%$ recurrence rate was reported after surgical excision, and $43.5 \%$ after cauterization alone (17). Lai et al. (12) and Sataloff and Hawkshaw (13) also reported recurrence of $\mathrm{LCH}$ despite intensive medical anti-reflux and voice therapy after surgical excision. In the current case, surgical excision was performed and then the patient was given anti-reflux therapy proton pump inhibitor and antibiotics - amoxicillin + clavulanic acid for one month. Although it was very small compared to the initial lesion, recurrence was seen three months after the surgical treatment.

\section{CONCLUSION}

In conclusion, LCH is rarely located in the larynx. Symptoms may be mild or profound, such as respiratory distress, depending on the lesion's size. The main reasons for the formation of $\mathrm{LCH}$ are trauma and chronic irritation to the larynx and it should be noted that it may recur despite different treatment options.

\section{ACKNOWLEDGEMENTS}

\section{Financial Support}

This research received no specific grant from any funding agency, commercial or not-for-profit sectors.

The study was presented at the $36^{\text {th }}$ Turkish $\mathrm{Na}$ tional Congress of Otorhinolaryngology and Head \& Neck Surgeryy, November 5-9, 2014, Antalya, Turkey

\section{REFERENCES}

1. Fechner RE, Cooper PH, Mills SE. Pyogenic granuloma of the larynx and trachea. A causal and pathologic misnomer for granulation tissue. Arch Otolaryngol. 1981;107:30-32.

2. Nkanza NK, Hutt MS. Pyogenic granuloma: a study of 181 cases from Malawi. East Afr Med J. 1981;58:318-323.

3. Kerr DA. Granuloma pyogenicum. Oral Surg Oral Med Oral Pathol. 1951;4:158-176. 
4. Vilmann A, Vilmann P, Vilmann H. Pyogenic granuloma: evaluation of oral conditions. Br J Oral Maxillofac Surg. 1986;24:376-382.

5. Angelopoulos AP. Pyogenic granuloma of the oral cavity: statistical analysis of its clinical features. J Oral Surg. 1971;29:840-847.

6. Karlıdağ T, Yalçın Ş, Akpolat N, et al. Pyogenic granuloma of the epiglottis: a case report. Türk Otolarengoloji Arşivi. 2007; 45: 41-44.

7. Patrice SJ, Wiss K, Mulliken JB. Pyogenic granuloma (lobular capillary hemangioma): a clinicopathologic study of 178 cases. Pediatr Dermatol. 1991;8:267-276.

8. Jafek BW, Wood RP 2nd, Dion M. Granuloma pyogenicum. Ear Nose Throat J. 1977; 56:228-233.

9. Garrett MM, Lee WT. Obstructing pyogenic granuloma as a result of blunt laryngeal trauma. Otolaryngol Head Neck Surg. 2007;136:489-490.

10. el-Sayed Y, al-Serhani A. Lobular capillary haemangioma (pyogenic granuloma) of the nose. J Laryngol Otol. 1997;111:941-945.

11. Rechtman I, Armstrong PJ. Pyogenic granuloma of the vocal fold. Anaesth Intensive Care. 1982;10:372.

12. Lai S, Kelleher K, Sataloff RT. Vocal fold granuloma: the "ball-valve" phenomenon. Ear Nose Throat J. 2000;79:836.

13. Sataloff RT, Hawkshaw MJ. Multiple bilateral vocal fold cysts and recurrent pyogenic 'granuloma'. Ear Nose Throat J. 2001;80:72.

14. Yakirevitch A, Fridman E, Bedrin L. Pyogenic granuloma arising from vallecula. Otolaryngol Head Neck Surg. 2006;134:175-176.

15. Wenig BM, Heffner DK. Contact ulcers of the larynx. A reacquaintance with the pathology of an often underdiagnosed entity. Arch Pathol Lab Med. 1990;114:825-828.

16. Walner DL, Parker NP, Kim OS, Angeles RM, Stich DD. Lobular capillary hemangioma of the neonatal larynx. Arch Otolaryngol Head Neck Surg. 2008;134:272-277.

17. Mills SE, Cooper PH, Fechner RE. Lobular capillary hemangioma: the underlying lesion of pyogenic granuloma. A study of 73 cases from the oral and nasal mucous membranes. Am J Surg Pathol. 1980;4:470-479.

18. Truong MT, Perkins JA, Messner AH, Chang KW. Propranolol for the treatment of airway hemangi- omas: a case series and treatment algorithm. Int J Pediatr Otorhinolaryngol. 2010;74:1043-1048.

19. Galos D, Chowdhury FR, Gupta R, Heman-Ackah YD, Sataloff RT. Recurrent pyogenic granuloma in a noncompliant patient. Ear Nose Throat J. 2014;93:32-33.

20. Chambres O, Wiorowski M, Perrot JB, Kennel P. Pyogenic granuloma of the vocal cords: a case report. Rev Laryngol Otol Rhinol (Bord). 2002;123:129-131. 